\title{
Type and Concentration of Sea Grass and Effect on Nutrition Content of Sago Cookies
}

\author{
Johanis Fritzgal Rehena ${ }^{1}$, Zasendy Rehena ${ }^{2}$ \\ ${ }^{1}$ Professor of Biology Education Studies Program, in FKIP Unpatti-Ambon, Indonesia \\ ${ }^{2}$ Lecturer of Gizi Studies, in Public Health Faculty UKIM-Ambon, Indonesia
}

\begin{abstract}
Seaweed chemically composed of water (27.8\%), protein (5.4\%), carbohydrates (33.3\%), fat (8.6\%), crude fiber (3\%) and ash (22.25\%). Iodine is a very important element for the formation of thyroid hormones. This experimental study using a randomized block design is collated in a factorial design consisting of two independent variables which types of seaweed are Eucheumacottonii and Sargassumcrassifolium. The concentration of seaweed consisting of four levels, namely $10 \%, 20 \%, 30 \%$, 40\%. The dependent variable observed is carbohydrate, protein, and vitamin $A$ and iodine cookies. The average content of carbohydrates in the treatment Sargassumcrassifolium higher by $58.51 \%$ compared with $57.01 \%$ of Eucheumacottonii. Protein sago cookies in the treatment of seaweed species Sargassumcrassifolium at a concentration of $10 \%$ is equal to $10.41 \%$, a concentration of $20 \%$ is equal to $7.65 \%$, the concentration of $30 \%$ is equal to $5.59 \%$, and a concentration of $40 \%$ was $3.63 \%$. The higher the concentration of seaweed is added, the higher the fiber content. There is an increasing amount of vitamin A sago cookies along with the addition of grass concentration of $10 \%, 20 \%, 30 \%$ and $40 \%$. Average iodine content of sago cookies in treatment Eucheumacottonii at a concentration of $10 \%$ is equal to $29.76 \mathrm{~g}$, a concentration of $20 \%$ is equal to $41.56 \mathrm{~g}$, $30 \%$ concentration of $60.22 \mathrm{~g}$, and the concentration of $40 \%$ amounting to $80.58 \mathrm{~g}$.
\end{abstract}

Keywords: type and concentration of seaweed, nutrition sago cookies

\section{Introduction}

Today an estimated 42 million people in Indonesia who suffered GAKI, and of that number 295,000 of them suffer from mental disability as a midget, dumb, deaf and mental disorders as a result of GAKI (Kartono, 2006). Securities that are very well known people as a result of iodine deficiency is goiter or goiter, the enlargement of the thyroid gland in the neck area. In 1991, a survey conducted in eastern Indonesia (Maluku, Irian Jaya, East Nusa Tenggara) on 174929202 school children and pregnant women, obtained goiter in school children of $12-13 \%$ and $16-39 \%$ of pregnant women. Then in 1998 conducted a national survey of school children, mumps obtained on the national level is $9.8 \%$ and in 2003 rose to $11.1 \%$. Maluku Province is second only to East Nusa Tenggara goiter prevalence rate as high as 33.3\% (Gunanti\&Triyono, 2004).

Central Maluku district, is one of the areas in Maluku are included in a group that has a very high prevalence GAKI reached 38.6\% (Central Maluku Health Office, 2005). The increasing prevalence of GAKI in Central Maluku district due to consumption patterns are more dominated by the type of food source goitrogenik. Most people also do not have access to iodized salt. Coverage of households consumes iodized salt in Central Maluku district was 44.1\% (Central Maluku Health Office, 2008). The strategy of the government to address the problem is to provide a supplement GAKI iodized oil capsules in endemic areas and iodized salt program. Iodized capsule supplementations programs are short-term programs are very expensive. Iodized salt program that the government has done since 1990, until now has not gone well so that the perceived need for the presence of other programs more grounded approach food based, namely the development of diversification of food consumption that naturally contain iodine higher (Sumarmi and Chess, 2000 ).
Iodine is a very important element for the formation of thyroid hormones. The hormone is necessary for normal growth, physical and mental development. Djokomoeldjanto (1993) says that humans cannot create an item of iodine in the body, but must get it from outside the body naturally through the uptake of iodine contained in food and beverages. Approximately $75 \%$ of these iodine in the thyroid gland are used to synthesize the hormone thyroxin, tetraiodotironin (T4) and Triodotironin (T3) in which the hormones are necessary for growth and development and mental physical (Brody, 1999). Under normal circumstances the daily intake for an adult ranges from 100-150 $\mu \mathrm{g}$ per day. The adequacy of iodine is recommended for the people of Indonesia, among others: 1) age 0 to 9 years of its needs for $50-120 \mu \mathrm{g} ; 2$ ) aged $10-59$ and $>60$ years of $150 \mu \mathrm{g}$ (Male); 3) aged 10-59 and $>60$ years of $150 \mu \mathrm{g}$; 4) Pregnant women received an additional $+25 \mu \mathrm{g}$; lactating women 0 12 months at $+50 \mu \mathrm{g}(\mathrm{WHO}, 2001)$. Iodine can be obtained from various types of food and its content varies depending on the origin of the food items produced. Food from the sea is a source of natural iodine. Other sources of iodine salt and water fortification (Muchtadi, 1992).

Based on statistical data of fisheries and marine Maluku Province in 2006, the production of seaweed in the Maluku province of 2244.9 tons with the highest production in Central Maluku district amounted to 1092.6 tones (Department of Fisheries and Marine Maluku, 2007). From the results of the initial survey by researchers, seaweed commonly found in the region of Central Maluku district is genera Eucheuma and Sargassum, while the cultivated species are Eucheumacottonii. See the phenomenon of nutritional problems above, with the support of the local food potential to anticipate their critical malnutrition created a food product that can meet the criteria as an alternative food, ie cookies by using corn starch as raw material with the addition of seaweed. The main composition of the seaweed Eucheumacottonii that can be used as a food

Volume 6 Issue 1, January 2017

www.ijsr.net

Licensed Under Creative Commons Attribution CC BY 


\section{International Journal of Science and Research (IJSR) \\ ISSN (Online): 2319-7064}

Index Copernicus Value (2015): 78.96 | Impact Factor (2015): 6.391

ingredient is carbohydratesie $12.90 \%, 5.91 \%$ crude fiber and protein content ranged from 5.12 to $9.20 \%$. The most important nutrient content is actually on trace elements, particularly iodine which ranged from 0.1 to $0.15 \%$ of the dry weight (Matanjun, et al, 2008). Vitamin AEucheumacottonii is $59.39 \mathrm{IU} / \mathrm{kg}$ (Sunarto, 2003). Generally seaweed Sarggasumcrasifolium yet widely known and exploited, but from several studies reported that seaweed has a fairly high nutrient content. CrasifoliumSarggasumcarbohydrate content was $19.06 \%$, $5.53 \%$ protein and $28.39 \%$ crude fiber. Iodine content is 0.1 to $0.8 \%$, and vitamin A $489.55 \mathrm{IU} / 100 \mathrm{~g}$ dry weight (Handy et al, 2004).

Further research Laeggeng (2001) it can be proved that it contains the amino acid lysine in seaweed $0.004 \%$, while methionine is not contained therein. The results Matanjun et al (2008) that analyzes the nutritional content of Eucheumacottonii and research results Handayani et al (2004) who analyzed the composition of Sargassumcrasifolium nutrition acquired 16 amino acids contained in Eucheumacottonii and Sargassumcrasifolium in different amounts. Generally Eucheumacottonii has a spherical morphology thallus transparent, soft as cartilage, green, brown or reddish purple. Thallus slippery surface there is sometimes a semicircular protrusion (Afrianto\&Liviawaty, 1993).

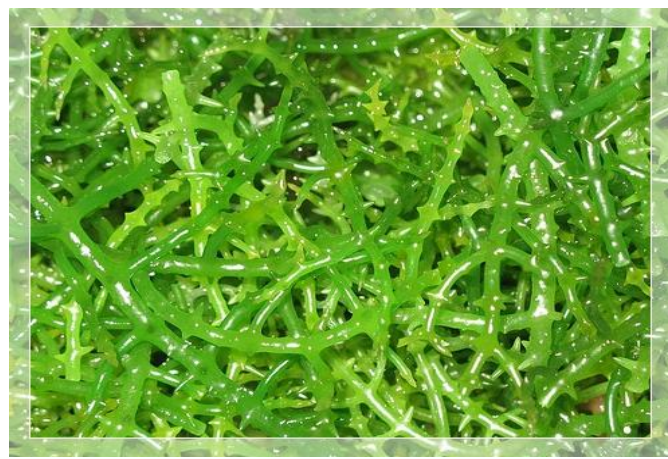

Figure 1: Eucheumacottonii

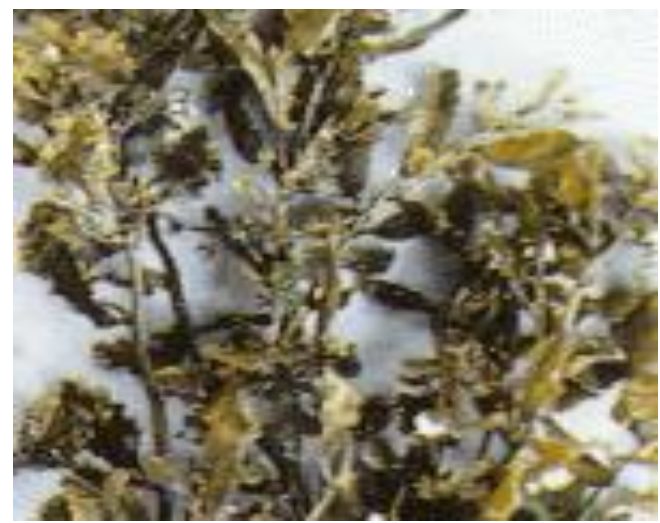

Figure 2: Sarggasumcrassifolium

Seaweed contains nutrients that are complete enough Seaweed chemically composed of water $(27.8 \%)$, protein (5.4\%), carbohydrates $(33.3 \%)$, fat $(8.6 \%)$, crude fiber $(3 \%)$ and ash (22.25\%) (Winarno, 1996). Kadir study (2000) showed that the iodine content of juice Eucheumacottonit range of $1.23 \mathrm{ppm}$ to $1.82 \mathrm{ppm}$, while in the fresh form Eucheumacottonii iodine content was $2.83 \mathrm{ppm}$. The fiber content ranges from $2.66 \%$ to $2.83 \%$, while in the fresh form ranges from $3.90 \%$. Starch / corn starch containing 3.69 to $5.96 \%$ dietary fiber and carbohydrates from 80.35 to $85.90 \%$ as well as several other nutritional values. Constraints are fairly basic content of sago is the concentration of nutrients. Sago has carbohydrate content greater than with other food ingredients, but the levels of protein, fat and other micronutrients are lower than other food items and even some that are not contained in corn starch (Pietris, 2005). Corn starch nutrient content can be seen in Table 1 .

Table 1: Nutritional content Sago Flour Compared Other Food

\begin{tabular}{|c|c|c|c|c|c|c|}
\hline Komponen & Tepungsagu & Beras & Ubikayu & Ubijalar & Jagungkuning & Terigu \\
\hline Air (\%) & 14,00 & 13,00 & 63,00 & 16,00 & 12,00 & 13,00 \\
\hline Calorie (kal) & 357,00 & 366,00 & 98,00 & 123,00 & 335,00 & 330,00 \\
\hline Protein (\%) & 1,40 & 7,60 & 0,70 & 1,80 & 9,20 & 11,00 \\
\hline Lipid (\%) & 0,20 & 0,80 & 0,10 & 0,70 & 3,90 & 2,00 \\
\hline Carbohydrate (\%) & 85,90 & 80,40 & 23,70 & 27,90 & 73,70 & 72,40 \\
\hline Calcium (\%) & 11,00 & 24,00 & 19,00 & 30,00 & 14,00 & 15,00 \\
\hline Iron (mg) & 1,40 & 1,90 & 0,60 & 0,70 & 2,80 & 2,00 \\
\hline Thiamin (mg) & 0,01 & 0,10 & 0,04 & 90,00 & 0,29 & 170,00 \\
\hline Riboflavin (mg) & 0,00 & 0,05 & 0,03 & $?$ & 0,11 & $?$ \\
\hline Niacin (mg) & 0,00 & 2,10 & 0,40 & 3,12 & 2,10 & $?$ \\
\hline Vitamin A (IU) & 0,00 & 0,00 & 0,00 & 770,00 & 510,00 & 0,00 \\
\hline
\end{tabular}

(Source: WidyaKarya National Food and Nutrition. LIPI, Jakarta. 1998)

Cookies are one snack food that has been known and loved by the people and is generally preferred by children. Product cookies are generally made from flour raw material which is still imported a total of 2 million tons per year and this number is likely to increase from year to year (Ministry of Industry, 1990). Given the value of imports of wheat flour that is large enough, then the effort to be able to replace the use of wheat is to use corn starch. This study aims to determine the effect of type and concentration of seaweed on the nutrient content of sago cookies.

\section{Volume 6 Issue 1, January 2017 www.ijsr.net}




\section{International Journal of Science and Research (IJSR) \\ ISSN (Online): 2319-7064}

Index Copernicus Value (2015): 78.96 | Impact Factor (2015): 6.391

\section{Research Methods}

This experimental study using a randomized block design is collated in a factorial design consisting of two independent variables. The first factor is the types of seaweed areEucheumacottonii and Sargassumcrassifolium. The second factor is the concentration of seaweed consisting of four 4 levels, namely $10 \%, 20 \%, 30 \%, 40 \%$. Factors controlled temperature, heating time, and additives in the dough cookies. The dependent variable observed is the nutrient content of cookies that include carbohydrate, protein, and vitamin A and iodine. More experimental design consists of eight levels $(2 \times 4)$ each repeated 3 times, in order to obtain 24 units of trial.

The subjects were dried sago flour and seaweed. Dried sago flour used in this study is a kind of dry corn starch Tuni, obtained from supermarkets in Central Maluku district. Seaweed used is Eucheumacottonii and Sargassumcrasifolium taken directly from the Central Maluku regency. The tools used in the manufacture of certain cookies in good condition, dry and clean. Tools are prepared include: blenders, scales, dough container, Solet plastic, aluminum trays, molds, oven. The main raw material used is dry corn starch, wheat flour, seaweed is processed into powdered seaweed. Other additives are egg yolks, margarine, powdered sugar, vanilla.

The main tool used to test the carbohydrate content was Spectrophotometer, while its complement tool is an analytical balance, a test tube, a water bath, beaker, pipette. Materials used are standard glucose (glucose anhydrous), Reagensia Nelson A (sodium carbonate anhydrous, Rochelle salt, Sodium Bicarbonate, Sodium Sulfate anhydrate and distilled water), Reagensia Nelson B (CuSO4.5H2O solution, distilled and concentrated sulfuric acid), a solution arsenolydat (ammonium molybdic, distilled water, concentrated sulfuric acid and $\mathrm{Na} 2 \mathrm{HaSO} 4.7 \mathrm{H} 2 \mathrm{O}$ ). Tools to test the protein content is pumpkin Kejdahl, analytical balance models TL-2102, the brand Pyrex measuring cup, pipette. Materials used are $\mathrm{K} 2 \mathrm{SO} 2, \mathrm{HgO}, \mathrm{H} 2 \mathrm{SO} 4$, distilled water, $\mathrm{NaOH}-\mathrm{Na} 2 \mathrm{~S} 2 \mathrm{O} 3$. Tools to test iodine content is spectrophotometers and tools complements is an analytical balance, a test tube, flask, pipette, thermometers, calorimeters, oven, vortex. Materials used are Cerium ammonium sulphate, $\mathrm{NaOH}, \mathrm{KNO} 3$, acid chlorite, acid arsenate. Tools for fiber test mouthpieces Bucher, Erlenmeyer, filter paper, box scales. Materials needed are $\mathrm{NaOH}$, H2SO4, ethanol, hot water. The tools used for Vitamin A are Chromatography Column. Materials needed are acetone, petroleum ether, a mixture of alumina and anhydrous Na2SO4 (1: 1), fine sand, the material to be measured its vitamin A content. The procedures for making powdered seaweed harvested at low tide each washed using fresh water as he removed the dirt on seaweed such as sand, rocks, and then separated from other types. Once clean, sun dried seaweed. Dried seaweed then sieve to remove dirt that remains then packed in plastic bags and then transported to a laboratory clean Agricultural Technology UNMUH Malang.

Dried seaweed that has been milled with a mill, and then sifted with a fine sieve (100 mesh) is then used as a fortification ingredient in the manufacture of sago cookies.
Before the raw material used first chemical analysis. Preliminary test conducted to obtain optimal substitution of corn starch to wheat products cookies that can be accepted by the consumer (public) through organoleptic test. The formulations used is the ratio between flour with corn starch (\% of total flour) at a rate of 100: 0 (\% of wheat flour to be used as a control), 80:20, 60:40, 40:60, 30:70, $20: 80$, 10:90. having known optimal substitution of corn starch that is still possible to use it to do biscuit which was then modified by seaweed with a concentration of $10 \%, 20 \%$, $30 \%$ and $40 \%$. Making Cookies Sagu by adding seaweed as follows. Mix the egg yolks, margarine and powdered sugar then whipped with a mixer on speed 2 for \pm 5 minutes, in order to mix the price of margarine, eggs, and sugar. Furthermore, input flour substituted corn starch and the addition of seaweed powder with a concentration corresponding treatments, $10 \%, 20 \%, 30 \%$ and $40 \%$. The addition of seaweed determined $100 \%$ by weight of flour used. then mix with a mixer with a speed of 1 for \pm 5 minutes, after which it is stirred briefly to obtain a homogenous dough. All the ingredients that have made mixed dough sheet with a thickness of $0.5 \mathrm{~cm}$ and is printed with the same size. Baking uses a temperature of $160^{\circ}$ for 30 minutes. Cookies are ripe removed from the oven, cooled and stored in an airtight jar to test nutrient content. Determination of carbohydrate content using spectrophotometry way, Nelson-Somogyi method (AOAC, 1970).

Determination of protein content using the macro method Kjeldhal modified (AOAC, 1984). The procedure of determining the total protein content can be seen in Appendix 3. Determination of crude fiber content with Oven method (AOAC, 1984). Determining the content of vitamin $\mathrm{A}$ is to determine the content of carotenoids with Carr-price method (AOAC, 1992). Determination of iodine content using Cerium (Sandel-kothloff method) (Gunanti, 1999). The principle arsenate acid (AsO3) reducing the $\mathrm{Ce}$ (yellow) to $\mathrm{Ce}$ (colorless) with the rest of the non-reduced $\mathrm{Ce}$, measured with a spectrophotometer at a wavelength of 4-20 nm. This research was conducted at the Laboratory of Agricultural Technology, University of MuhammadiyahMalang. The influence of the type and concentration of seaweed on the nutrient content were analyzed by ANOVA double. The criteria of significance was $5 \%$. If the calculation results with analysis of variance showed differences significant then continued by Duncan Multiple Range Test (DMRT).

\section{Results and Discussion}

\section{a. Content of Carbohydrates}

Data sago cookies carbohydrate content of the treatment type and concentration of seaweed Different shown in Figure 2.

\section{Volume 6 Issue 1, January 2017




\section{International Journal of Science and Research (IJSR) ISSN (Online): 2319-7064}

Index Copernicus Value (2015): 78.96 | Impact Factor (2015): 6.391

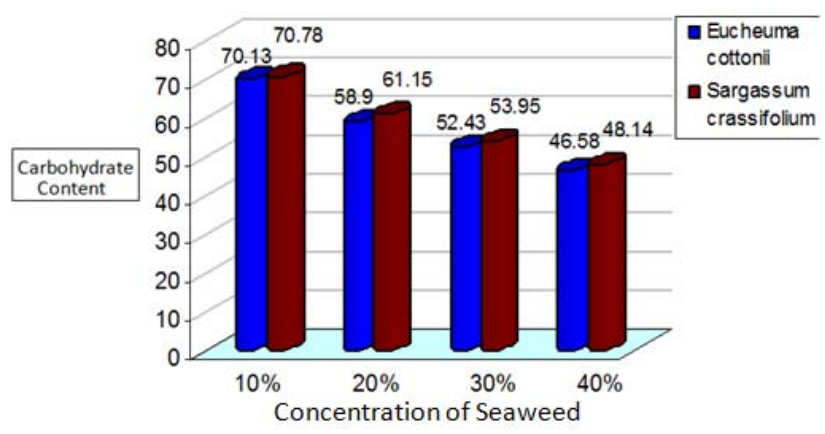

Figure 2: Carbohydrate Content of Sago Cookies Based Treatment. The type and concentration of Seaweed

The average carbohydrate content sago cookies in the treatment of seaweed species Eucheumacottonii with a concentration of $10 \%$ is equal to $70.13 \%$, a concentration of $20 \%$ amounting to $58.9 \%$, the concentration of $30 \%$ amounting to $52.43 \%$, and a concentration of $40 \%$ by 46 , $58 \%$. The average carbohydrate content sago cookies in the treatment of seaweed species Sargassumcrassifolium shows that at concentrations of $10 \%$ is equal to $70.78 \%$, a concentration of $20 \%$ is equal to $61.15 \%$, the concentration of $30 \%$ amounting to $53.95 \%$, and a concentration of $40 \%$ amounting to $48.14 \%$. Sago cookies carbohydrate content tends to decrease with increasing concentration of seaweed starting on SargassumcrassifoliumorEucheumacottoni. This shows that the higher the concentration added, the decrease in carbohydrate content sago cookies

\section{b. The content of Protein}

Sago cookies protein content data based on treatment type and concentration of seaweed Different shown in Figure 3.

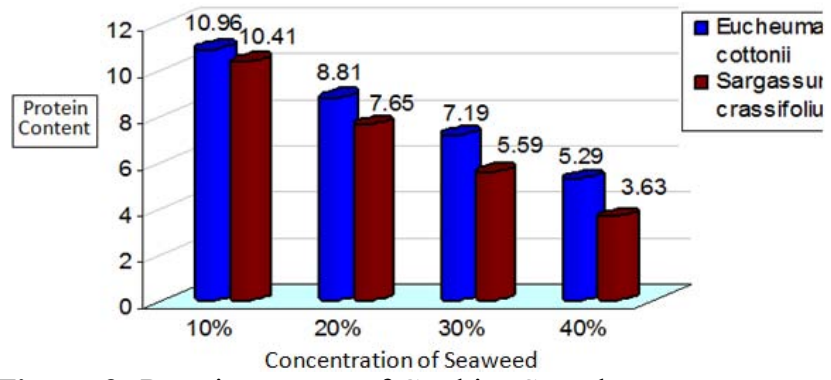

Figure 3: Protein content of Cookies Sago by treatment type and Concentration Seaweed

The average protein content of corn cookies on the treatment of seaweed species Eucheumacottonii at a concentration of $10 \%$ is equal to $10.96 \%$, a concentration of $20 \%$ is equal to $8.81 \%$, the concentration of $30 \%$ is equal to $7.19 \%$, and a concentration of $40 \%$ by $5.29 \%$. The average protein content of corn cookies on the treatment of seaweed species Sargassumcrassifolium at a concentration of $10 \%$ is equal to $10.41 \%$, a concentration of $20 \%$ is equal to $7.65 \%$, the concentration of $30 \%$ is equal to $5.59 \%$, and a concentration of $40 \%$ is by $3.63 \%$. A decrease in protein content sago cookies along with the addition concentration of seaweed. The higher the concentration of seaweed is added then decreasing the protein content.

\section{c. The content of fiber}

Data fiber sago cookies based on treatment type and concentration of seaweed Different shown in Figure 4.

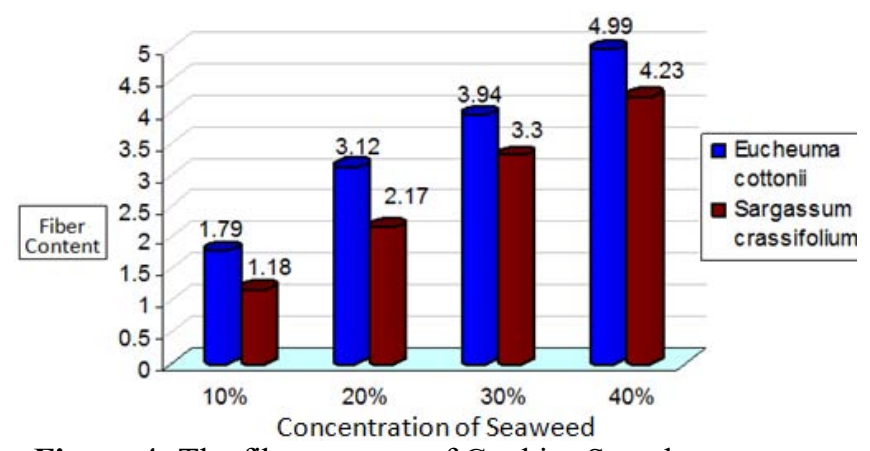

Figure 4: The fiber content of Cookies Sago by treatment type and Concentration Seaweed

The fiber content of sago cookies in treatment Eucheumacottonii at a concentration of $10 \%$ is at $1.79 \%$, a concentration of $20 \%$ is equal to $3.12 \%$, the concentration of $30 \%$ by $3.94 \%$, and $40 \%$ concentration of $4.99 \%$. Average fiber content in treatment Sargassumcrassifolium with a concentration of $10 \%$ was $1.18 \%$, a concentration of $20 \%$ was $2.17 \%, 30 \%$ concentration of $3.30 \%$, and the concentration of 40 is $4.23 \%$. The higher the concentration of seaweed is added, the higher the fiber content.

\section{d. Vitamin A}

Data content of vitamin A sago cookies based on treatment type and concentration of seaweed Different shown in Figure 5

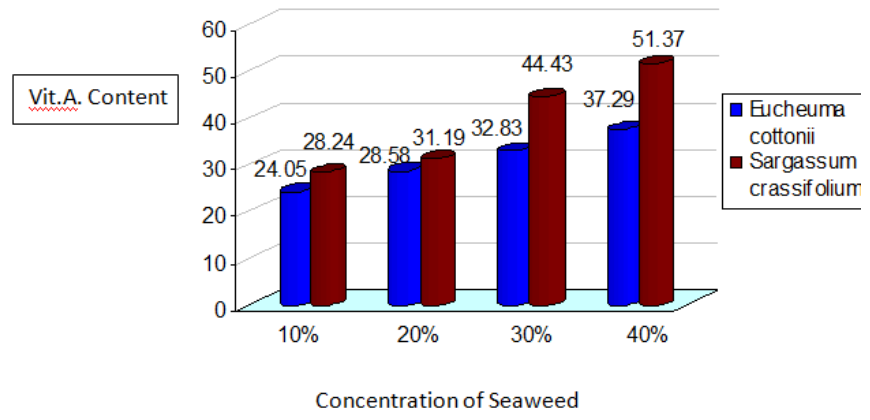

Figure 5: Vitamin A Sago Cookies Based Treatment. The type and concentration of Seaweed

The content of vitamin A in the treatment of sago cookies Eucheumacottonii at a concentration of $10 \%$ is equal to $24.05 \mathrm{SI}$, a concentration of $20 \%$ is equal to $28.58 \mathrm{SI}$, concentration of $30 \%$ is equal to 32.83 SI, and a concentration of $40 \%$ amounting to $37.29 \mathrm{SI}$, The average content of vitamin A in the treatment of Sargassumcrassifolium with a concentration of $10 \%$ is equal to 28.24 SI, a concentration of $20 \%$ is equal to 31.19 SI, concentration of $30 \%$ is equal to $44.43 \mathrm{SI}$, and a concentration of 40 amounted to 51.37 SI. There is an increasing amount of vitamin A sago cookies along with the addition concentration of seaweed that was started $10 \%$, $20 \%, 30 \%, 40 \%$, this shows that the higher the concentration of seaweed is added, the higher content of vitamin A.

\section{e. The content of iodine}

Sago cookies iodine content data based on treatment type and concentration of seaweed Different shown in Figure 6.

\section{Volume 6 Issue 1, January 2017




\section{International Journal of Science and Research (IJSR) ISSN (Online): 2319-7064}

Index Copernicus Value (2015): 78.96 | Impact Factor (2015): 6.391

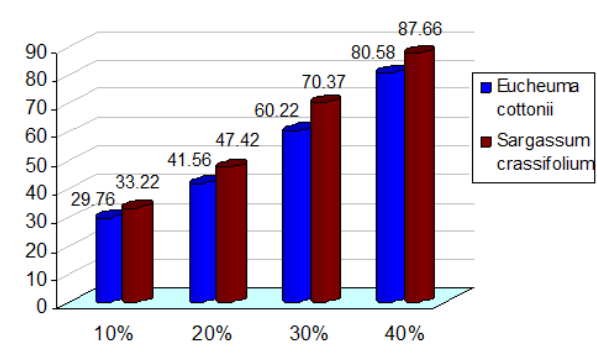

Concentration of Seaweed

Figure 6: The content of Iodine Based Sago Cookies.

Treatment of type and concentration of Seaweed

Average iodine content of sago cookies in treatment Eucheumacottonii at a concentration of $10 \%$ is equal to $29.76 \mathrm{~g}$, a concentration of $20 \%$ is equal to $41.56 \mathrm{~g}, 30 \%$ concentration of $60.22 \mathrm{~g}$, and the concentration of $40 \%$ amounting to $80.58 \mathrm{~g}$. The average content of iodine in the treatment of Sargassumcrassifolium with a concentration of $10 \%$ is equal to $33.22 \mathrm{~g}$, a concentration of $20 \%$ is equal to $47.42 \mathrm{~g}, 30 \%$ concentration is equal to $70.37 \mathrm{~g}$, and the concentration of 40 is equal to $87.66 \mathrm{~g}$, The higher the concentration of seaweed is added, the higher the iodine content.

\section{f. Sago Cookies Mixed Seaweed}

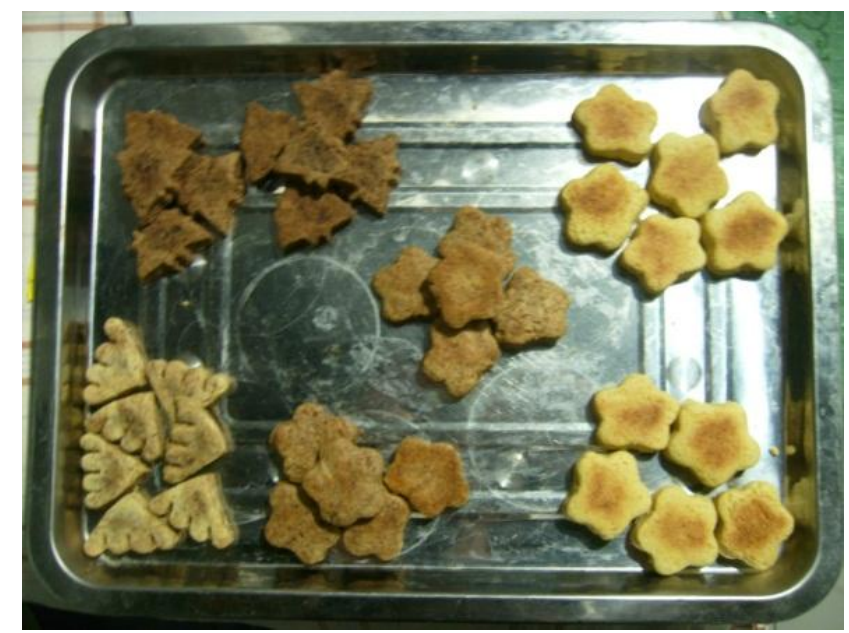

Figure 7: Cookies Sago by treatment type and concentration of Seaweed(Source: Research Results)

Analysis of the influence of the type and concentration of seaweed as well as its interaction with carbohydrate, protein, fiber, vitamin A and iodine content is shown in Table 2, 3, 3.4, 5 and Table 6.

Table 2: Analysis of VarianceEffect of type and concentration of Seaweed and Interaction on Carbohydrate Content of Sago Cookies

\begin{tabular}{|c|c|c|c|c|c|}
\hline Source & $\begin{array}{c}\text { Type III Sum } \\
\text { of Squares }\end{array}$ & df & $\begin{array}{c}\text { Mean } \\
\text { Square }\end{array}$ & F & Sig. \\
\hline Corrected Model & $1787,931(\mathrm{a})$ & 7 & 255,419 & 91,313 & 0,000 \\
\hline Intercept & 80069,222 & 1 & 80069,222 & 28624,861 & 0,000 \\
\hline J & 13,440 & 1 & 13,440 & 4,805 & 0,044 \\
\hline K & 1772,581 & 3 & 590,860 & 211,233 & 0,000 \\
\hline J K & 1,909 & 3 & 0,636 & 0,228 & 0,876 \\
\hline Error & 44,755 & 16 & 2,797 & & \\
\hline Total & 81901,908 & 24 & & & \\
\hline Corrected Total & 1832,686 & 23 & & & \\
\hline
\end{tabular}

Value of $\mathrm{F}$ for the treatment of a type of seaweed on the carbohydrate content of sago cookies amounted to 4.805 with 0.044 significance. The significance value is smaller than the alpha value of 0.05 . This shows that there are differences in the carbohydrate content of sago cookies in treatment Eucheumacottonii and Sargassumcrassifolium. The average content of carbohydrates in the treatment Sargassumcrassifolium higher by $58.51 \%$ compared with $57.01 \%$ of Eucheumacottonii. $\mathrm{F}_{\text {cal }}$ value for the concentration of seaweed treatment amounted to 211.233 with 0.000 significance. It showed no effect of concentration of seaweed on the carbohydrate content of sago cookies. Wong and Cheung (2000) states that brown seaweed has a higher carbohydrate content than the red seaweed. Results of research Mantanjun et al (2008), showed that the average content of carbohydrates Eucheumacottonii was $26.49 \pm$ 3.01 , and the average Sargassumcrassifolium carbohydrate content of $33.49 \pm 1.70$.

Table 3: Analysis of Variance Effect of type and concentration of Seaweed ad Interaction of the Protein Content of Sago Cookies

\begin{tabular}{|c|c|c|c|c|c|}
\hline Source & $\begin{array}{c}\text { Type III Sum } \\
\text { of Squares }\end{array}$ & df & $\begin{array}{c}\text { Mean } \\
\text { Square }\end{array}$ & F & Sig. \\
\hline Corrected Model & $137,171(\mathrm{a})$ & 7 & 19,596 & 203,452 & 0,000 \\
\hline Intercept & 1329,677 & 1 & 1329,677 & 13805,265 & 0,000 \\
\hline J & 9,300 & 1 & 9,300 & 96,558 & 0,000 \\
\hline $\mathrm{K}$ & 126,687 & 3 & 42,229 & 438,440 & 0,000 \\
\hline $\mathrm{J}^{*} \mathrm{~K}$ & 1,184 & 3 & 0,395 & 4,096 & 0,025 \\
\hline Error & 1,541 & 16 & 0,096 & & \\
\hline Total & 1468,389 & 24 & & & \\
\hline Corrected Total & 138,712 & 23 & & & \\
\hline
\end{tabular}

Treatment of seaweed species to the protein content of sago cookies at 96.558 with significance 0.000 . No effect of type of seaweed on the protein content of seaweed is received. No difference in the average protein content of corn cookies on treatment Eucheumacottonii and Sargassumcrassifolium. The average protein content in the treatment Eucheumacottonii amounted $8,07 \%$ higher than Sargassumcrassifolium amounted to $6.82 \%$. Red and green seaweed higher in protein than brown seaweed which is equal to $8-20 \%$ of the weight of the wet, while the brown seaweed containing protein by $3-9 \%$. Results of research Sanchez et al (2004) showed that the protein content Eucheumacottonii of $9.76 \pm 1.33$ of Sargassumcrassifolium dry weight of $5.40 \pm 0.07$.

Table 4: Analysis of Variance Effect of type and concentration of Seaweed and Fiber Content Interaction against Sago Cookies

\begin{tabular}{|c|c|c|c|c|c|}
\hline Source & $\begin{array}{c}\text { Type III Sum } \\
\text { of Squares }\end{array}$ & df & $\begin{array}{c}\text { Mean } \\
\text { Square }\end{array}$ & F & Sig. \\
\hline Corrected Model & $35,606(a)$ & 7 & 5,087 & 115,200 & 0,000 \\
\hline Intercept & 229,525 & 1 & 229,525 & 5198,272 & 0,000 \\
\hline J & 3,271 & 1 & 3,271 & 74,077 & 0,000 \\
\hline K & 32,233 & 3 & 10,744 & 243,340 & 0,000 \\
\hline J * & 0,101 & 3 & 0,034 & 0,766 & 0,530 \\
\hline Error & 0,706 & 16 & 0,044 & & \\
\hline Total & 265,838 & 24 & & & \\
\hline Corrected Total & 36,312 & 23 & & & \\
\hline
\end{tabular}

\section{Volume 6 Issue 1, January 2017 www.ijsr.net}




\section{International Journal of Science and Research (IJSR) \\ ISSN (Online): 2319-7064}

Index Copernicus Value (2015): 78.96 | Impact Factor (2015): 6.391

Value of $F$ for the treatment of a type of seaweed on the fiber content of sago cookies at 74.077 with a significance of 0.000 , showed no effect on the type of seaweed seaweed fiber content. There is a very real difference in average fiber sago cookies between treatments Eucheumacottonii with Sargassumcrassifolium. The average fiber content in treatment Eucheumacottonii higher by 3.46 by 2.72 of Sargassumcrassifolium. Value of $\mathrm{F}$ for the treatment concentration of the seaweed fiber content sago cookies at 243.340 in significance 0.00 . The significance value is much smaller than the alpha value of 0.05 , there is the influence of the concentration of seaweed fiber content sago cookies. Kadir (2000) explains that the fiber content ranges from $2.66 \%$ to $2.83 \%$, while in the fresh form is in the range of $3.90 \%$. Dietary fiber from seaweed red and brown varied, also in the seaweed fiber content is strongly influenced by the type of seaweed, the red algae consisting of starch Floridian ( $\alpha$ 1,4 glycan), cellulose, xylenes and mannan.

Table 5: Analysis of Variance Effect of type and concentration of Seaweed And Vitamin A Interaction on Sago Cookies.

\begin{tabular}{|c|c|c|c|c|c|}
\hline Source & $\begin{array}{c}\text { Type III Sum } \\
\text { of Squares }\end{array}$ & df & $\begin{array}{c}\text { Mean } \\
\text { Square }\end{array}$ & F & Sig. \\
\hline Corrected Model & $1729,608(a)$ & 7 & 247,087 & 222,559 & 0,000 \\
\hline Intercept & 30247,420 & 1 & 30247,420 & 27244,814 & 0,000 \\
\hline J & 555,266 & 1 & 555,266 & 500,146 & 0,000 \\
\hline K & 1092,856 & 3 & 364,285 & 328,123 & 0,000 \\
\hline J K & 81,486 & 3 & 27,162 & 24,466 & 0,000 \\
\hline Error & 17,763 & 16 & 1,110 & & \\
\hline Total & 31994,792 & 24 & & & \\
\hline Corrected Total & 1747,372 & 23 & & & \\
\hline
\end{tabular}

Treatment types of seaweed on the content of vitamin A sago cookies amounted to 500.146 with signification 0,000 , this means that there is influence of the type of seaweed on the content of vitamin A sago cookies. There is a significant difference in the average content of vitamin $\mathrm{A}$ in the treatment of sago cookies Eucheumacottonii and Sargassumcrassifolium. The average content of vitamin A in the treatment of Sargassumcrassifolium at 51.37 is higher than Eucheumacottonii at 30.69. Seaweed treatment concentration of the vitamin A content of 328.123 with a 0.00 significance means that there is the influence of the concentration of seaweed against vitamin A sago cookies. Sunarto research results (2003) showed that the amount of vitamin A Eucheumacottoniiamounted to $59.393 \mathrm{IU} / \mathrm{kg}$, while research Handayani et al, gained an average of $\beta$ carotene levels in the Sargassumcrassifolium amounted to $489.55 \mathrm{pg}$ RE / $100 \mathrm{~g}$ dry weight. Based on the results of previous studies it can be concluded that the levels of vitamin A Sargassumcrassifolium higher than in Eucheumacottonii.

Table 6: Summary of Analysis of Variance Effect of type and concentration of Seaweedand Interaction of the iodine content of Cookies Sago

\begin{tabular}{|c|c|c|c|c|c|}
\hline Source & $\begin{array}{c}\text { Type III Sum } \\
\text { of Squares }\end{array}$ & df & $\begin{array}{c}\text { Mean } \\
\text { Square }\end{array}$ & F & Sig. \\
\hline Corrected Model & $9959,335(\mathrm{a})$ & 7 & 1422,762 & 491,831 & 0,000 \\
\hline Intercept & 76213,375 & 1 & 76213,375 & 26345,998 & 0,000 \\
\hline J & 264,604 & 1 & 264,604 & 91,470 & 0,000 \\
\hline K & 9659,867 & 3 & 3219,956 & 1113,098 & 0,000 \\
\hline J * K & 34,864 & 3 & 11,621 & 4,017 & 0,026 \\
\hline
\end{tabular}

\begin{tabular}{|c|c|c|c|c|c|}
\hline Error & 46,285 & 16 & 2,893 & & \\
\hline Total & 86218,995 & 24 & & & \\
\hline Corrected Total & 10005,619 & 23 & & & \\
\hline
\end{tabular}

Treatment types of seaweed on iodine content sago cookies at 91.470 with a significance of 0.000 . This shows that there is a very real difference in the average iodine content of sago cookies in treatment Eucheumacottonii and Sargassumcrassifolium. The average content of iodine in the treatment of Sargassumcrassifolium of $59.67 \mathrm{~g}$ higher than Eucheumacottonii amounted to $53.03 \mathrm{~g}$. The test results seaweed treatment concentration of the iodine content amounted to 1113.098 with signification 0,000 , it shows there is a very significant difference average iodine content of sago cookies on the treatment concentration of seaweed different. According to Winarno (1990) Seaweed is rich in trace elements, especially iodine and iodine content differed among species is. Red seaweed has iodine content ranges between $0.10-0.15 \%$, and the brown seaweed ranged from 0.10 to $0.80 \%$. The results of the study Laenggeng et al (2005) also concluded that the addition of seaweed on the idea caused an increasing iodine content is at $30 \%$ concentration of iodine content increased to $81.00 \mathrm{~g}$. Similarly, the increase in iodine content noodle products along with the increasing concentration of seaweed. Irianto, K (2014) describes the content of Iodine deficiency causes Swelling on the neck where the thyroid gland which is located below and beside larynx. The thyroid gland produces hormones that control the speed or the amount of the body's metabolism.

\section{Conclusions and Recommendations}

Treatment of type and concentration of seaweed significantly affect carbohydrate, protein, fiber, vitamin A and iodine content cookies. The carbohydrate content of cookies on treatment Sargassumcrassifolium higher than Eucheumacottonii. The fiber content cookies in treatment Eucheumacottonii higher than Sargassumcrassifolium. The fiber content is highest at $40 \%$ concentration of sea grass. Cookies iodine content in treatment Sargassumcrassifolium higher than Eucheumacottonii. The fiber content is highest at $40 \%$ concentration of sea grass. The addition of seaweed concentration causes an increase in iodine content cookies

Suggested research has potential use of seaweed as a food source of iodine, to promote seaweed food products must be accompanied by efforts to cultivating seaweed Eucheumacottonii and Sargassumcrassifolium in central Maluku district, with support by relevant agencies. Increasing the value of iodine content, fiber, and vitamin A on cookies sago fortified with seaweed, is expected to help meet the needs substance of iodine in the body, also play a positive role in the government's efforts to tackle problems due to iodine deficiency (GAKI) in Central Maluku, and prevent the risk of degenerative diseases.

\section{References}

[1] Afrianto, E., Liviawaty. 1993. BudidayaRumputLautdancaraPengolahannya. Jakarta: BhrataraNiaga Media.

\section{Volume 6 Issue 1, January 2017




\section{International Journal of Science and Research (IJSR) \\ ISSN (Online): 2319-7064 \\ Index Copernicus Value (2015): 78.96 | Impact Factor (2015): 6.391}

[2] AOAC. 1984. Official Methods of Analysis of The Association of Official Agriculture Chemist. Washington DC.

[3] Brody, T. 1999. Nutritional Biochemistry. Second Edition. Academic Press, University of California.

[4] DinasPerikanandanKelautanPropinsi Maluku. 2007. PengembanganBudidayaRumputLautMelaluiKlasterGer bangEkonomiKerakyatan. http://www.bi.go.id/NR/rdonlyres/D5C867DO-D1DE4317-BD8D/boks. Diakses 13 Mei 2009

[5] Dinkes Maluku Tengah. 2005. LaporanTahunanCakupan Program GiziTahun 2005 , Masohi.

[6] DepartemenPerindustrian. 1990. StandartIndustri Indonesia (SII): StandarMutuBiskuit (SII: 0177-90.

[7] Djokomoeljanto. 1993. PeranZatGiziMikro (Iodium) DalamMenurunkanAngkaMorbiditiasAnak. Gizi Indonesia. 17: 6-14

[8] Gunanti, I.R \&Triyono. 2004. IdentifikasiFaktor yang DidugaBerhubungandenganKejadianGondokpadaAnak SekolahDasar di Daerah DataranRendah. Jurnal GAKI Indonesia Vol. 3, N0; 1-3 April, AgustusdanDesember 2004.

[9] Handayani, T., Sutarno\&Setyawan, A.D. 2004.Analisis

KomposisiNutrisiRumputLautSargassumcrasifolium . JurnalBiofarmasi 2 (2): 45-52 Agustus 2004. http://www.scribd.com/doc/12814193/f020201.

Diaksestanggal 3 October 2009.

[10]Irianto, $\mathrm{K}$.

2014. EpidemiologiPenyakitMenulardanTidakMenular. PanduanKlinis. Bandung. ALFABETA.

[11]Kadir, S. 2000. StudiKandunganGizi Juice RumputLaut. Tesis. IlmuKesehatanMasyarakatUnairSurabaya.

[12]Kartono. 2006. Indikator Total Goiter Rate (TGR) AnakSekolahSebagaiDasarKebijakanProgram GAKI di Indonesia. Jurnal GAKI Indonesia Vol. 5, N0; 1 April 2006

[13]Laenggeng, A.H \&Giman. 2005. Pemanfaatan Rumput Lautdalam Meningkatkan Kandungan Iodiumdan Seratpada PembuatanTahu. JurnalNeptunus, Vol. 11 No.2 Januari 2005: 86-92.

[14]Matanjun, P., Mohamed, S., Mustapha, M \&Kharidah. 2008. Nutrient content of tropical edible seaweeds, Eucheumacottonii, Caulerpalentillifera and Sargassumpolycystum.Journal of Applied Phycology, 10.1007/s10811-008-9326-4.

[15]Muchtadi, $1992 . \quad$ MasalahmasalahFortifikasilodiumdanPenanggulangan GAKI. PAU: IPB Bogor.

[16]Pietris. D, 2005. The Optimalization of Sago for Food Diversivication, Agribusiness, Water/ Land Resource Conservation and Poverty Reduction of Returness in Waii Village, Maluku Province, Indonesia. Final Report. The Waiselaka Foundation-United Nations Industrial Development Organization (UNIDO).

[17] Sánchez, M. DI., Hernández, L.J \&Paseiro, L.P. 2004. Fatty acids, total lipid, protein and ash contents of processed edible seaweeds. Journal Food Chemical 85:439-444.
[18]Sumarmi, S.A \&Catur, A. 2000. MasalahGizi di Indonesia. Jakarta. ProyekPengembanganGiziKesmas. DirjenPendidikanTinggiDepdiknas.

[19]Sunarto. 2003. PotensiNutrisiRumputLaut (Eucheumacottonii) SebagaiSumberBahanPakan. Skripsi. Program StudiNutrisidanMakananTernak. FakultasPerikananIPB

[20]WidyaKaryaNasionalPangandanGizi,. 1998. jakarta: LIPI.

[21]Winarno, F.G, 1996. TeknologiPengolahanRumputLaut. Jakarta: PustakaSinarHarapan.

[22]Winarno, F.G. 2002. Kimia PangandanGizi. Jakarta: GramediaPustakaUtama.

[23]Wong KH \& Cheung CK. 2000. Nutritional evaluation of some subtropical red and green seaweeds. Part 1proximate composition, amino acid profiles and some physico-chemical properties. Journal Food Chemical $71: 475-482$ 